\title{
EVALUATION OF METHODS FOR ERWINIA AMYLOVORA DETECTION
}

\author{
Monika KAŁUŻNA, Joanna PUŁAWSKA*, Artur MIKICIŃSKI \\ Research Institute of Horticulture \\ Konstytucji 3 Maja 1/3, 96-100 Skierniewice, Poland
}

Received: November 22, 2013; Accepted: December 15, 2013

\begin{abstract}
Phytosanitary measures to control diseases require sensitive and reliable detection methods. In case of Erwinia amylovora, the causal agent of fire blight, there are several methods developed. We tested six of them: (1) a conventional method; (2) standard PCR; (3) BIO-PCR; (4) Real-time PCR with SYBR Green; (5) Real-time PCR with TaqMan probe; and (6) Loop Mediated Isothermal Amplification (LAMP) in terms of their specificity, sensitivity and repeatability. Of the methods tested, only Real-time PCR with SYBR Green amplified non-specific fragments, which could be however identified by melting curve analysis. Real-time PCRs (both with SYBR Green and TaqMan probe) and LAMP were most sensitive and allowed to detect E. amylovora even in the samples where the concentration of cells was lower than $2 \times 10^{1} \mathrm{cfu} /$ reaction. The highest repeatability was obtained using conventional method and Real-time PCRs. Of the methods used, only the LAMP technique was very insensitive to plant impurities.
\end{abstract}

Key words: asymptomatic plant material, fire blight, LAMP, PCR, Real-time PCR

\section{INTRODUCTION}

Fire blight, caused by Erwinia amylovora, is one of the most destructive diseases of apples and pears in Poland. Besides parasitic relationship, the pathogen can survive in plants as endophyte or as an epiphyte on plant surfaces. Early and quick detection of E. amylovora plays an important role in disease prediction, elimination of potential fire blight foci, as well as in testing of trees before planting and planning control treatment schedules. The most common methods of fire blight diagnostics, like isolation of bacteria on selective or semi-selective media, pathogenicity tests and serological assays are time consuming and/or not always specific and sensitive enough. DNA-based methods, particularly PCR, offer the possibility to overcome these constraints and allow fast detection of E. amylovora with high specificity and sensitivity. The aim of our study was to evaluate and compare six methods (a conventional and five molecular) of E. amylovora detection in terms of their specificity, sensitivity and repeatability.

\section{MATERIALS AND METHODS}

\section{Bacterial strains and DNA isolation}

In the years 1982-2011, strains of Erwinia amylovora were isolated on SNA medium (Nutrient Agar (Difco) with 5\% saccharose) from symptomatic apple and pear tree tissues originating from different geographical regions of Poland. After isolation, they were purified, tested for their pathogenicity on immature pear fruitlets (Sobiczewski \& Millikan 1985) and deposited in the collection of the Laboratory of Bacteriology at the Research Institute of Horticulture. As a reference, a well-described and sequenced strain B62 (ATCC 49946) (Sebaihia et al. 2010) was used. Bacterial DNA from pure culture or from plant tissue was isolated using the $\mathrm{Ge}$ nomic Mini kit (A\&A Biotechnology, Gdynia, Poland). One $\mu 1$ of DNA was used in all techniques based on DNA amplification.

\section{Methods of $E$. amylovora detection}

Six methods of E. amylovora detection were tested: 


\section{Conventional method}

Bacteria were plated on microbiological media SNA and King's medium B (King et al. 1954). After $48 \mathrm{~h}$ of incubation at $26^{\circ} \mathrm{C}$, bacteria were identified based on colony morphology on these two media.

2. Standard PCR with primers complementary to chromosomal DNA (Maes et al. 1996)

Bacterial DNA $(1 \mu \mathrm{l})$ was amplified by PCR with primers EaF (5'-GCGCAGTAAAGGGTGACAG CCCCGTACACAAAAAGGCACT-3') and EaR (5'-CCCTAGCCGAAACAGTGCTCTACCCCCG

G-3'). Amplification was carried out in a Biometra T3000 Thermocycler (Biometra GmbH, Gottingen, Germany) with reaction conditions described by Maes et al. (1996). PCR products were separated on a $1.5 \%$ agarose gel in TBE buffer, which was stained with ethidium bromide $\left(0.5 \mathrm{mg} \cdot \mathrm{l}^{-1}\right)$ and visualized under a UV transilluminator.

\section{BIO-PCR}

PCR with primers complementary to chromosomal DNA (Maes et al. 1996) was preceded by overnight incubation of a homogenate of the tested sample on SNA medium. Bacterial growth was washed from the medium with $3 \mathrm{ml}$ of $0.01 \mathrm{M}$ PBS buffer $(0.27 \%$ $\mathrm{Na}_{2} \mathrm{HPO}_{4} ; 0.04 \% \mathrm{NaH}_{2} \mathrm{PO}_{4} ; 0.8 \% \mathrm{NaCl}$ ) and $1 \mathrm{ml}$ of suspension was used for isolation of DNA using the Genomic Mini kit according to manufacturer instructions (A\&A Biotechnology, Gdynia).

\section{Real-time PCR with SYBR Green}

Real-time PCR was conducted with primers complementary to plasmid pEA29 and the amplification product was detected with SYBR Green dye (Fast Start Universal SYBR Green Master, Roche Diagnostics GmbH/Applied Science, Mannheim, Germany). One $\mu l$ of bacterial DNA was used for PCR with primers P29TF 5'-CACTGATGGTGCCGT TG-3' and P29TR 5'-CGCCAGGATAGTCGCA TA-3' (Salm \& Geider 2004). Amplification was carried out on Rotor Gene 6000 (Corbett Life Science) with the protocol and reaction conditions as described by Salm and Geider (2004). In order to verify the specificity of amplification in Real-time PCR with SYBR Green, the melting curve analysis of the obtained products was performed at the end of the reaction. After preconditioning of PCR products at $60{ }^{\circ} \mathrm{C}$ for $90 \mathrm{~s}$, progressive denaturation of products was carried out at a temperature rising from 60 to $90{ }^{\circ} \mathrm{C}$ with $1{ }^{\circ} \mathrm{C}$ increment. As the temperature increases, $\mathrm{PCR}$ products dissociate (SYBR Green is released) and their melting temperature depends on the length and the composition of the sequence. As a result, it is possible to observe a decrease in fluorescence for dissociating products. The peaks corresponding to the melting temperature of DNA products can be identified on the plot of $\mathrm{dF} / \mathrm{dT}$ (negative first derivative of fluorescence versus temperature). At this step, by comparison with the results of positive control, the specificity of obtained products is being determined.

\section{Real-time PCR with TaqMan probe}

The primers and the TaqMan probe were complementary for plasmid pEA29: primers P29TF and P29TR as above and P29TM (TaqMan probe) 5'-TACCTCCGCAGCCGTCATGG-3' (Salm \& Geider 2004). The TaqMan probe was labelled at the $5^{\prime}$ end with 6-carboxyfluorescein (FAM) and at the $3^{\prime}$ end with 6-carboxy-tetramethyl-rhodamine (TAMRA). The protocol and reaction conditions were as described by Salm and Geider (2004) but Platinum Taq DNA Polymerase (Invitrogen) was used. The reaction was conducted on Rotor Gene 6000 (Corbett Life Science).

\section{Loop Mediated Isothermal Amplification (LAMP)}

LAMP is a one-step amplification reaction that amplifies a target DNA sequence under isothermal conditions. LAMP employs a Bst or Bsm DNA polymerase with strand-displacement activity, along with two inner primers (FIP, BIP) and outer primers (F3, B3) which recognize six separate regions within a target DNA (Notomi et al. 2000). The high number of DNA regions, which has to be simultaneously recognized by the primers to obtain amplification products, provides high specificity of detection. Detection of E. amylovora using LAMP was carried out with primers complementary to ams $H$ gene located on chromosomal DNA (Moradi et al. 2012). One $\mu 1$ of bacterial DNA was added to the amplification mixture of which the content was as originally described by Moradi et al. (2012) but Bsm polymerase (Thermo Scientific) was used. Incubation was performed at $60{ }^{\circ} \mathrm{C}$ as optimal for Bsm polymerase. LAMP products were separated on $1.5 \%$ agarose gels in TBE buffer, which were stained with 
Table 1. Origin and characteristics of E. amylovora strains used in detection sensitivity tests

\begin{tabular}{cclcc}
\hline Strain & Origin & Host plant & Year of isolation* & Virulence \\
\hline E2 & Poland/Oświęcim & Crataegus sp. & 2000 & low \\
692 & Poland/Nowy Dwór & Sorbus sp. & 1997 & moderate \\
659 & Poland/Torun & Malus sp. & 1986 & moderate \\
A90 & USA & Malus pumila & nd & high \\
B62 & USA & Malus pumila & nd & high \\
\hline
\end{tabular}

* No data

ethidium bromide $\left(0.5 \mathrm{mg} \cdot \mathrm{l}^{-1}\right)$ and visualized under a UV transilluminator.

\section{Specificity and sensitivity of tested methods}

Specificity of each method was evaluated with 60 strains of E. amylovora or their DNA, one Pseudomonas syringae strain 110 and two Xanthomonas arboricola strains: X507 and L31.

To estimate the sensitivity of E. amylovora detection, five strains: B62, A90, 692, 659 and E2, isolated from different plant species, in different years and different geographical regions and of different virulence were selected (Table 1). The suspensions of these strains $\left(2 \times 10^{8} \mathrm{cfu} \cdot \mathrm{ml}^{-1}\right)$ were prepared. Then the suspensions were serially diluted 10 times and each dilution was used in the conventional method and in BIO-PCR. From $100 \mu$ lof each dilution, bacterial DNA was isolated and afterwards used in methods based on DNA amplification.

For assessment of the sensitivity of E. amylovora detection in plant material, $2-3 \mathrm{~cm}$ long apple shoot fragments $(1.2 \pm 0.2 \mathrm{~g})$ were surface sterilized with $70 \%$ ethanol, cut into small fragments, and placed in a glass tube with $3 \mathrm{ml}$ of $0.01 \mathrm{M}$ PBS buffer with addition of $100 \mu 1 E$. amylovora suspension of different concentrations $\left(10^{5}, 10^{4}, 10^{3}, 10^{2}, 10^{1}\right.$ and $\left.10^{0} \mathrm{cfu} \cdot \mathrm{ml}^{-1}\right)$. The concentration of bacterial cells in each suspension was estimated by plating $100 \mu 1$ of suspensions of $10^{1}-10^{4} \mathrm{cfu} \cdot \mathrm{ml}^{-1}$ (each in three repetitions) on SNA medium and counting colonies grown after overnight incubation at $26^{\circ} \mathrm{C}$. After addition of bacterial suspension to plant material, samples were incubated on a rotary shaker for $1 \mathrm{~h}$ at room temperature. One hundred $\mu l$ of obtained washings was plated on SNA medium to estimate the sensitivity of conventional method and BIOPCR. Additionally, $1 \mathrm{ml}$ of washings was centrifuged, the pellet was re-suspended in $100 \mu 1$ of TE buffer (10 mM Tris-Cl, $\mathrm{pH}$ 8.0, $1 \mathrm{mM}$ EDTA) and DNA was isolated as described above. The obtained DNA was used in tests on sensitivity of DNA-based detection methods.

\section{Repeatability of tested methods}

E. amylovora suspensions of five strains: B62, A90, 692,659 and E2 $\left(2 \times 10^{5}, 2 \times 10^{4}, 2 \times 10^{3}, 2 \times 10^{2}\right.$ and $2 \times 10^{1} \mathrm{cfu} \cdot \mathrm{ml}^{-1}-$ the number of bacterial cells was counted as described above), were used for testing repeatability of the conventional method and BIOPCR. For estimation of repeatability of all tested DNA-based detection methods, DNA of E. amylovora isolated from the prepared suspensions as described above was applied. Each bacterial suspension, and each of its DNA, was tested five times.

\section{Susceptibility of DNA-based detection methods to contamination by plant impurities}

Fragments of apple tree tissue (leaves and shoot) were macerated and shaken in $2 \mathrm{ml}$ of 0.01 PBS buffer for $30 \mathrm{~min}$. The plant washings as well as their three 10fold dilutions were mixed $(1: 1 \mathrm{v} / \mathrm{v})$ with $1 \mu \mathrm{l}$ of E. amylovora DNA isolated from bacterial suspensions containing $2 \times 10^{5}, 2 \times 10^{4}, 2 \times 10^{3}, 2 \times 10^{2}$ and $2 \times 10^{1} \mathrm{cfu} \cdot \mathrm{ml}^{-1}$. The mixture was applied for tests with all DNA-based detection methods. Each combination of plant impurities - DNA was tested two times.

\section{Detection of $E$. amylovora in asymptomatic ma- terial}

For detection of E. amylovora in asymptomatic plant material, eight samples were collected from five orchards localized in central Poland in June 2013. Each sample consisted of 100 twigs, approximately $10 \mathrm{~cm}$ long, collected from 100 newly planted apple trees. In the laboratory, the twigs of each sample were disinfected, cut into small pieces 
and incubated in $500 \mathrm{ml}$ of sterile $0.01 \mathrm{M}$ PBS buffer for $30 \mathrm{~min}$ on the rotary shaker at room temperature. Afterwards, the washings were centrifuged and the pellet was re-suspended in $2 \mathrm{ml}$ of $0.01 \mathrm{M}$ PBS buffer. One hundred $\mu 1$ of the suspension was plated on King's medium B, SNA and CCT medium (Ishimaru \& Klos 1984). The remaining suspension was centrifuged, supernatant removed and the pellet used for DNA isolation with AxyPrep Multisource Genomic DNA Miniprep Kit (Axygen, Biosciences, USA). After overnight incubation on applied media, bacteria were washed off the plates with $2 \mathrm{ml}$ of PBS buffer and centrifuged. The pellets obtained were subjected to DNA isolation using the AxyPrep Multisource Genomic DNA Miniprep Kit (Axygen, Biosciences, USA). The isolated DNA was used for E. amylovora detection with application of standard PCR, Real-time PCRs and LAMP as described above. In parallel, we checked if fire blight occurred during summer in the orchards from which the samples were collected.

\section{RESULTS}

\section{Specificity and sensitivity of tested methods}

All tested methods, except Real-time PCR with SYBR Green, allowed for specific detection of all tested E. amylovora strains. In case of Real-time PCR with SYBR Green, non-specific products were obtained in reactions with DNA of Pseudomonas syringae and Xanthomonas arboricola. To differentiate specific and non-specific products, it was necessary to apply the product melting curve analysis. In case of samples with lower concentration of E. amylovora $\left(<10^{2}\right.$ cfu per reaction), the fluorescence signal for true E. amylovora appeared even later than in case of DNA of Pseudomonas and Xanthomonas strains, applied in a concentration of $10 \mathrm{ng} \cdot \mu \mathrm{l}^{-1}$. Real-time PCR with TaqMan probe was specific in our hands, with the samples we used, and detected only DNA of E. amylovora.
The sensitivity of detection of E. amylovora in pure bacterial culture differed depending on the methods tested. Both conventional method and standard PCR had the sensitivity threshold of $2 \times 10^{2}$ cfu per reaction (Fig. 1). Application of preincubation of a sample on microbiological medium (BIO-PCR) increased the sensitivity 100 times $\left(2 \times 10^{\circ}\right.$ cfu per reaction). Out of the DNA-based methods, the most sensitive detection was obtained with Real-time PCR (both with SYBR Green and TaqMan probe) and LAMP (Figs $2 \& 3$ ). These techniques allowed for detection of $E$. amylovora even when the concentration of bacterial cells was lower than $2 \times 10^{1}$ cfu per reaction.

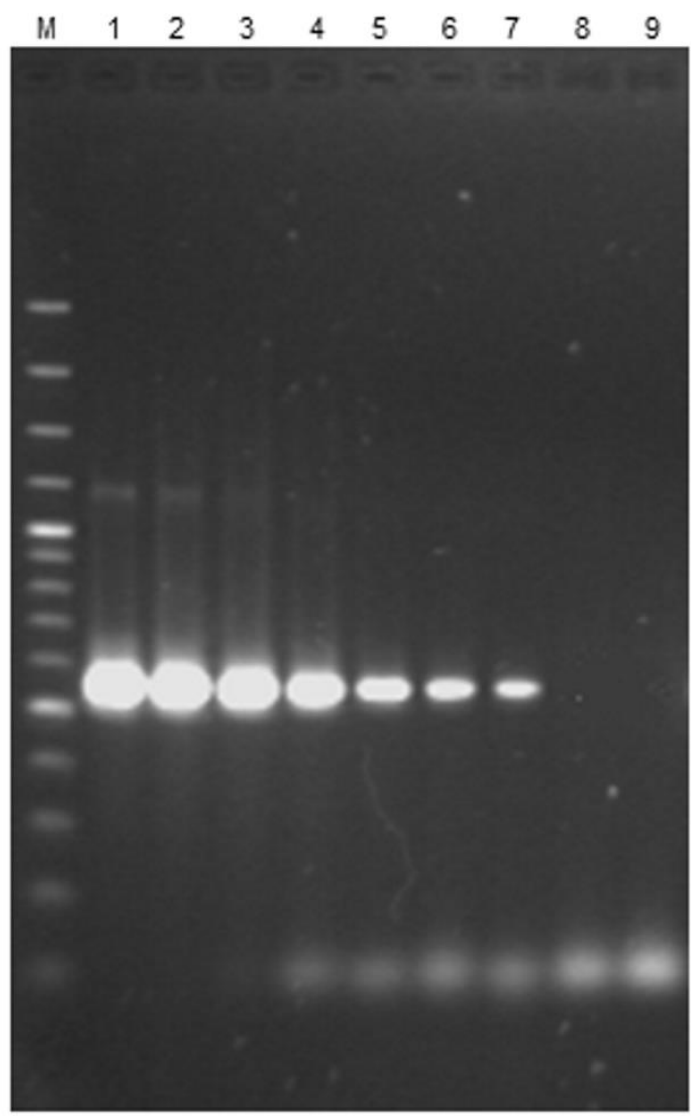

Fig. 1. Sensitivity of detection of E. amylovora in pure bacterial culture using standard PCR with primers EaF/EaR: M - marker 100 bp Ladder (Thermo Scientific Fermentas), $1-2 \times 10^{8}, 2-2 \times 10^{7}, 3-$ $2 \times 10^{6}, 4-2 \times 10^{5}, 5-2 \times 10^{4}, 6-2 \times 10^{3}, 7-2$ $\times 10^{2}, 8-2 \times 10^{1}$ and $9-2 \times 10^{0}$ cfu per reaction 


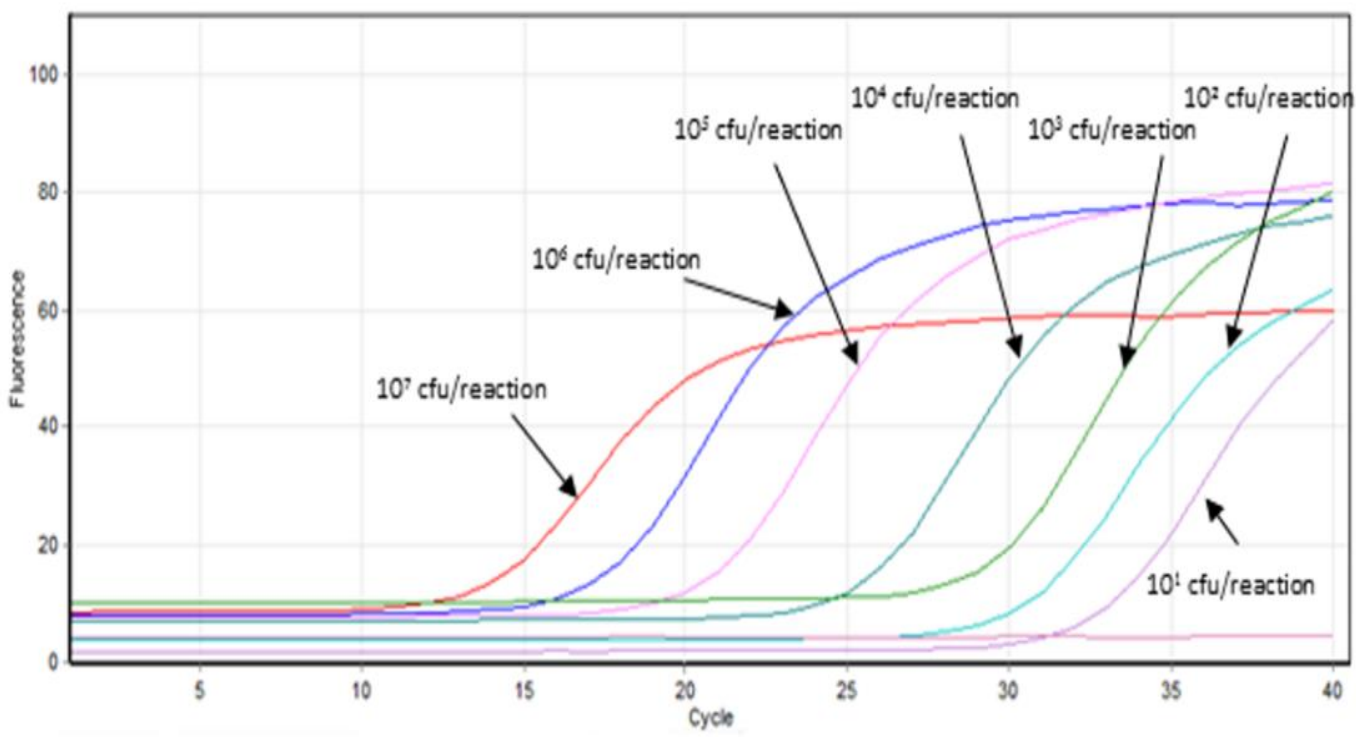

Fig. 2. Real-time PCR with SYBR Green for specific and quantitative amplification of Erwinia amylovora DNA. Fluorescence signal in relation to the amount of template

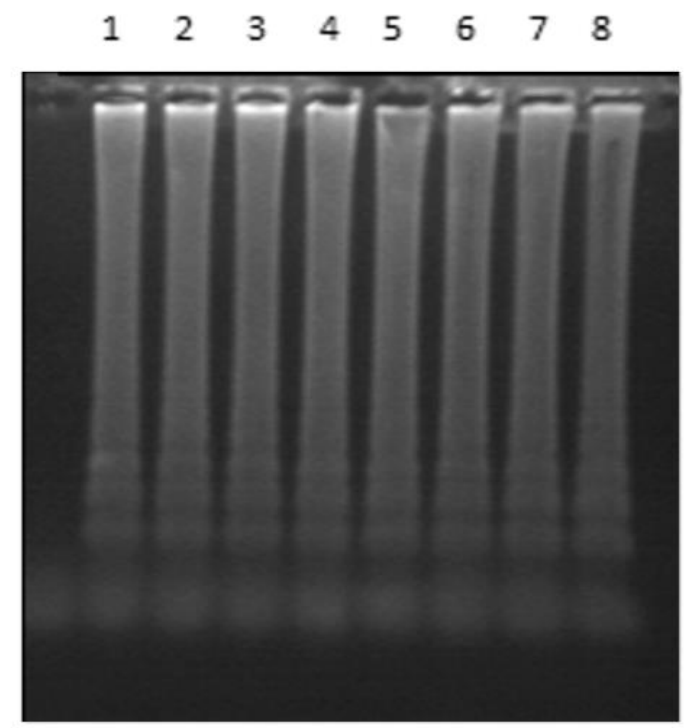

Fig. 3. Sensitivity of detection of E. amylovora with LAMP technique. Amplification profile was observed in samples of concentration: $1-2 \times 10^{7}$, $2-2 \times 10^{6}, 3-2 \times 10^{5}, 4-2 \times 10^{4}, 5-2 \times 10^{3}$, $6-2 \times 10^{2}, 7-2 \times 10^{1}, 8-2 \times 10^{0}$ cfu per reaction

In case of detection of E. amylovora in plant material, Real-time PCRs, both with TaqMan and SYBR Green, showed similar sensitivity as in pure bacterial culture $\left(<2 \times 10^{1}\right.$ cfu per reaction $)$ and it was the highest sensitivity out of all the tested methods. The lowest sensitivity of detection was obtained by the conventional method $\left(10^{3} \mathrm{cfu} \cdot \mathrm{ml}^{-1}\right)$. With standard PCR, the detection threshold was $2 \times 10^{2}$ cfu per reaction while BIO-PCR using SNA washings allowed increasing this sensitivity 100 times.

\section{Repeatability of tested methods}

All techniques tested differed in terms of repeatability. Classical microbiological method and Real-time PCRs were the most repeatable. Their repeatability was estimated as $100 \%$; this means that the same result was obtained in all repetitions tested. The standard PCR and BIO-PCR had repeatability equal to $80 \%$. The lowest repeatability, $20-60 \%$ depending on the bacteria concentration, was observed in LAMP technique.

\section{Susceptibility of DNA-based detection methods to contamination by plant impurities}

The LAMP technique was insensitive to plant impurities; amplification products were observed in all samples independently from E. amylovora DNA or plant extract concentration. Standard PCR was inhibited by concentrated plant extract and the efficiency of DNA amplification in the sample with 10 times diluted plant extract was much lower than that of pure DNA. Realtime PCR with SYBR Green was inhibited only by the most concentrated plant extract while in Real-time 
PCR with TaqMan probe fluorescence was observed even in case of highest concentration of plant impurities but the signal was detected 5 cycles later in comparison to pure DNA $(\Delta \mathrm{ct}=5)$. Plant extracts diluted 100 and 1000 times had no effect on detection with any of the tested methods.

\section{Detection of $E$. amylovora in asymptomatic ma- terial}

In asymptomatic samples of young apple shoots, E. amylovora was not detected using Real-time with SYBR Green. Although the fluorescent signal was observed for all samples, only for positive control (DNA of E. amylovora) the product of expected size (112 bp) was obtained, which was confirmed after melting curve analysis $\left(\mathrm{Tm}=87^{\circ} \mathrm{C}\right)$. It could be caused by the presence of high number of other bacteria isolated from samples, which DNA could be also amplified. When the amplification products were analysed on the electrophoresis gel, many DNA fragments of different sizes were observed; they surely were the reason of fluorescence but they had another size than the specific product. Real-time PCR with TaqMan probe gave positive signal for all tested samples, but the number of threshold cycle was higher than 30, which suggests that the amount of bacteria in the samples was rather low - it corresponds to the $10^{1}-10^{2}$ cfu per reaction according to the sensitivity measured on pure bacterial cultures (Fig. 2). Standard PCR showed positive results only in the samples, which were earlier preincubated on microbiological media. Using LAMP technique, E. amylovora was detected in the majority, 19 of 32 tested samples. Monitoring of the orchards from which the asymptomatic samples were collected revealed that fire blight was not observed in any of them in the year we made the survey, although the weather conditions during the season were very favourable for disease development.

\section{DISCUSSION}

Out of all tested methods, and with the plant samples we used, only Real-time PCR with SYBR Green showed non-specific results; a positive signal of reaction was observed also for other than E. amylovora tested bacteria. Originally, the primers used in this reaction were checked by their authors for specific- ity (Salm \& Geider 2004) but in that test only bacteria of other Erwinia species were included. However, based on the BLAST analysis (Altschul et al. 1990) the sequences of primers showed high homology and coverage to other bacteria, also belonging to Pseudomonas and Xanthomonas genus. This is quite important, because these bacteria, particularly Pseudomonas spp., are ubiquitous and are very often isolated from plant material. The disadvantage of both Real-time PCRs is the fact that the primers and probe are complementary to the sequence of the plasmid pEA29. Actually, pEA29 was historically the first target for designing the primers for $E$. amylovora detection (Bereswill et al. 1992) because it was thought that this plasmid is ubiquitous in all E. amylovora strains and due to its copy number, primers based on this plasmid will be more sensitive than chromosomal primers. Since then, several strains lacking pEA29 were found (Llop et al. 2006; Mohammadi et al. 2009), which means that application pEA29-based diagnostic system as the only technique can be risky.

Real-time PCRs appeared to be very sensitive and repeatable. Similar sensitivity was shown also by LAMP which has many advantages over PCR: it is reported to be faster, more specific, simpler to learn and interpret, not sensitive to plant origin compounds, doesn't require sophisticated equipment and is more adaptable to on-site implementation for field diagnostics (Gill \& Ghaemi 2008; Fang et al. 2010). However, the low repeatability of this technique, often observed in case of samples with low concentration of bacteria (F. Rezzonico, personal communication) can be the limit in reliable detection of pathogens.

Detection of E. amylovora in asymptomatic plants, although very important from a phytosanitary point of view, has been shown to be difficult (Anonymous 2013). In our study, although E. amylovora was detected in asymptomatic plant material with almost all techniques and methods used, it was not equivalent to the occurrence of fire blight symptoms in the orchards from where samples were collected. On the other hand, it could be connected to regular control treatments with copper preparations, which were done during the season. 


\section{Acknowledgement}

Authors thank J.L. Norelli from USDA-ARS-AFRS, Kearneysville, USA, for providing E. amylovora strains. This work was performed in the frame of Multi-annual Programme "Development of sustainable methods of horticultural production to ensure high biological and nutritional quality of horticultural products and to preserve the biodiversity of the environment and to protect its resources", task 1.6, financed by Polish Ministry of Agriculture and Rural Development.

\section{REFERENCES}

Altschul S.F., Gish W., Miller W., Myers E.W., Lipman D.J. 1990. Basic local alignment search tool. J. Mol. Biol. 215: 403-410. DOI: 10.1006/jmbi.1990.9999.

Anonymous 2013. PM 7/20 (2) Erwinia amylovora, EPPO Bulletin/Bulletin OEPP 43: 21-45.

Bereswill S., Pahl A., Bellemann P., Zeller W., Geider K. 1992. Sensitive and species-specific detection of Erwinia amylovora by polymerase chain-reaction analysis. Appl. Environ. Microb. 58: 3522-3526.

Fang X., Liu Y., Kong J., Jiang X. 2010. Loop-mediated isothermal amplification integrated on microfluidic chips for point-of-care quantitative detection of pathogens. Anal. Chem. 82: 3002-3006. DOI: 10.1021/ac1000652.

Gill P., Ghaemi A. 2008. Nucleic acid isothermal amplification technologies - a review. Nucleos. Nucleot. Nucl. 27: 224-243. DOI: 10.1080/15257770701845204.

Ishimaru C., Klos E.J. 1984. New medium for detecting Erwinia amylovora and its use in epidemiological studies. Phytopathology 74: 1342-1345. DOI: 10.1094/Phyto-74-1342.

King E.O., Ward M.K., Raney D.E. 1954. Two simple media for the demonstration of pyocyanin and fluorescin. J. Lab. Clin. Med. 44: 301-307.

Llop P., Donat V., Rodríguez M., Cabrefiga J., Ruz L., Palomo J.L., Montesinos E., López M.M. 2006.
An indigenous virulent strain of Erwinia amylovora lacking the ubiquitous plasmid pEA29. Phytopathology 96: 900-907. DOI: 10.1094/PHYTO96-0900.

Maes M., Garbeva P., Crepel C. 1996. Identification and sensitive endophytic detection of the fire blight pathogen Erwinia amylovora with $23 \mathrm{~S}$ ribosomal DNA sequences and the polymerase chain reaction. Plant Pathol. 45: 1139-1149. DOI: 10.1046/j.13653059.1996.d01-186.x.

Mohammadi M., Moltmann E., Zeller W., Geider K. 2009. Characterisation of naturally occurring Erwinia amylovora strains lacking the common plasmid pEA29 and their detection with real-time PCR. Eur. J. Plant Pathol. 124: 293-302. DOI: 10.1007/s10658-008-9417-8.

Moradi A., Nasiri J., Abdollahi H., Almasi M. 2012. Development and evaluation of a loop-mediated isothermal amplification assay for detection of Erwinia amylovora based on chromosomal DNA. Eur. J. Plant Pathol. 133: 609-620. DOI: 10.1007/s10658-012-9939-y.

Notomi T., Okayama H., Masubuchi H., Yonekawa T., Watanabe K., Amino N., Hase T. 2000. Loopmediated isothermal amplification of DNA. Nucleic Acids Res. 28, e63. DOI: 10.1093/nar/28.12.e63.

Salm H., Geider K. 2004. Real-time PCR for detection and quantification of Erwinia amylovora, the causal agent of fireblight. Plant Pathol. 53: 602610. DOI: 10.1111/j.1365-3059.2004.01066.x.

Sebaihia M., Bocsanczy A.M., Biehl B.S., Quail M.A., Perna N.T., Glasner J.D., DeClerck G.A., Cartinhour S., Schneider D.J., Bentley S.D., Parkhill J., Beer S.V. 2010. Complete genome sequence of the plant pathogen Erwinia amylovora strain ATCC 49946. J. Bacteriol. 192(7): 20202021. DOI:10.1128/JB.00022-10.

Sobiczewski P., Millikan D.F. 1985. Efficacy of chemicals for control of fire blight (Erwinia amylovora). Fruit Sci. Rep. 12: 27-34. 